\title{
Classic mycosis fungoides
}

INSERM

\section{Source}

INSERM. (1999). Orphanet: an online rare disease and orphan drug data base. Classic mycosis fungoides. ORPHA:2584

Classical mycosis fungoides is the most common type of mycosis fungoides (MF; see this term), a form of cutaneous T-cell lymphoma, and is characterized by slow progression from patches to more infiltrated plaques and eventually to tumors. 